\title{
PRESIDENT'S REPORT FOR THE 2004 NACA CONFERENCE
}

\section{Members, ladies and gentlemen}

It is my pleasure to report on a year in which NACA made demonstrable progress towards the achievement of its stated objectives.

\section{Legislative environment}

The Air Quality Bill has almost become an Act (National Environmental Management: Air Quality Act) at the end of a process during which NACA and its members were involved at every opportunity made available by the legislator. Included were workshops in each of the branches shortly after the first publication of the Bill for comment, an exhaustive written submission based on the discussion at these workshops, written and oral submissions to the Parliamentary Portfolio committee and an opportunity to discuss our comments in an individual discussion with departmental staff. Some of our criticisms were addressed; the department has explained why some were not. A legislative framework is now on the table; we look forward to further constructive engagement during the drafting of the regulations that are necessary for implementation.

Ambient air quality standards prepared by a technical committee of Standards South Africa (ex SABS) on which NACA members played a major role were published for public comment and attracted comment of an editorial nature only. The standards have therefore been published very recently as South African standards.

Thanks are due to the branches who organised the initial workshops from which the NACA written comment was collated, but especially to Yvonne Scorgie and her colleagues, who played a major role in drafting and editing the final comment paper and the draft ambient air quality standards and in doing so shaped our thinking about the future dispensation.

\section{Capacity building}

The need to build capacity for the implementation of the new Act has been widely recognised. DEAT has intimated that an implementation guide for local authorities will be published; a number of organisations have offered, or are planning to offer, training opportunities. Not the least of these are the NACA workshops offered by the Northern branch in conjunction with the 2004 conference. These brought internationally recognised experts on crucial aspects of air quality management to South Africa and they were very well attended, indicating that there is a demand for this type of intensive training. It is planned to make the proceedings available on the NACA website.

A training opportunity of a more general nature to be offered by a commercial conference/training organisation early in 2005 has been endorsed by Council after scrutiny of the programme and speaker schedule as it was felt that the NACA objectives were being advanced by this type of course. Council has decided that endorsement of such training courses, on condition that certain quality criteria are met, will continue to be considered.

\section{Publications}

In spite of our best efforts (and in spite of not paying the subscription fees for several months) we have not succeeded in killing the previous website, www.naca.co.za , for which apologies are offered. You will however have noted that the website has migrated to www.naca.org.za , which is much more vibrant than its predecessor thanks to Werner Illenberger who also finds time to do an almost solo job of running the Eastern Cape activities. The website really has become an up to date reflection of the multiple activities that characterise NACA and a repository of its history. It also offers a considerable number of useful links. Please go there and look at Werner's requests for material that will make the site even more useful this might be an opportunity to exercise that hidden talent as an author.

Newsletters appeared with their usual regularity, offering news items of a more immediate nature, while the Journal continued to publish general articles considered to be of interest to a majority of members. Efforts are being made to return publication of the Journal to its usual schedule, and we thank our advertisers whose continued support assists in covering publication cost.

A new source book for secondary school children is in the final stages of editing and should appear shortly. A practical guideline to ambient air quality monitoring has been prepared by Owen Pretorius and reviewed by two of our members active in this field; council is investigating methods of publication that will ensure wide and costeffective dissemination to its intended audience. Revival of previous efforts on a stack monitoring guideline is also being contemplated. 


\section{Branch activities}

These will be reported on seperately. The cliché that NACA lives through its branches is as true as ever, and I wish to record my thanks to the branch committees organising all of this. Grant Ravenscroft gallantly (and permanenttemporarily) stepped into the semi-breach left by Catherine Fedorsky's forced reduction in activities in the Western Cape; Werner does his thing in the Eastern Cape; Greg Scott and Gideon Slabbert chair active branches in Natal and the North respectively, while our immediate past president Jabu Sithole is the semi-permanent chair of the Soweto branch.

\section{Administration and Finances.}

Piet Odendaal as Technical Director and Roy Stephenson as Administrator continue their valued service to NACA, stoically enduring the upheavals caused by a determined cost-cutting effort by Council. Piet ably submitted our application for registration as a non-profit organisation, which exempts us from paying income tax. You will note from the seperately tabled financial report that the finances look increasingly healthy a slightly over-optimistic picture is presented by the fact that expenses associated with the above-mentioned publications are imminent, while a number of applications for bursaries are being considered by Council.

\section{Awards.}

Special mention must be made of the record number of awards that are to be made at the conference dinner in a number of categories. This reflects increased interest in air quality management in general, but also the facty that continued work of a high standard is being done in a number of areas. Congratulation to all awardees. We hope that this recognition of your work by the NACA membership will lead to continued effort on your part.

\section{And finally......}

My term as president has been greatly facilitated by dedicated efforts by council members, branch committees, the work of our permanent staff and the continued support of sponsors of symposia, of the annual conference and the advertisers in our Journal. All of this is recorded with gratitude.

I believe that our organisation still plays a leading role in the provision of clean air to all South African citizens, and request you continued support of the incoming president and council in their work to coordinate this.

\section{Gerrit Kornelius}

2004-10-07 